\title{
Dietary levels and sources of selenium for post weaning piglets
}

\author{
Tiago Ferreira Birro Oliveira ${ }^{1}$ Antônio Gilberto Bertechini ${ }^{{ }^{*}}$ \\ Renato Philomeno ${ }^{1}$ Vanessa Avelar Silva ${ }^{1}$
}

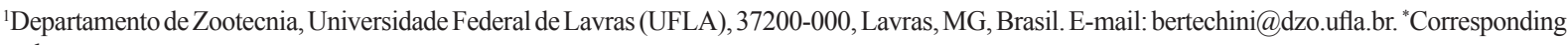
author.

\begin{abstract}
An experiment was conducted to study the effects of two sources and dietary levels of selenium (Se) on performance, Se concentration and glutathione peroxidase activity in plasma and liver of piglets post weaning. A total of 126 weaned pigs male and female Large White $\times$ Landrace, at average body weight of $7.2 \pm 0.67 \mathrm{~kg}$ were allotted to seven treatments in a randomized block design, with two Se sources (organic and inorganic), inclusion levels, two levels for the inorganic source (0.30 and 0.60ppm) and four for the organic source (0.15, $0.30,0.45$ and $0.60 \mathrm{ppm})$ and one control diet without Se supplementation containing $0.095 \mathrm{ppm}$, and six replicates of three animals per pen. The experimental period was 35 days post-weaning. The organic source contained $0.2067 \%$ (Se-yeast), and the inorganic $45.86 \%$ (sodium selenite) analyzed. Piglets that received supplemental Se had lower feed intake compared to those not supplemented. Furthermore, feed conversion was better with dietary supplementation of Se, and the organic source was better than the inorganic source at level of 0.30ppm. Plasma concentration of Se was higher (35.53\%) in animals receiving dietary supplementation of this mineral, regardless of the sources studied. There was no effect of sources on plasma and hepatic Se, with the lowest values observed for the non-supplementation and organic Se at dietary level of 0.15ppm. There was a linear reduction of plasma GSH-Px activity with increased supplementation levels of organic Se, and the hepatic GSH-Px activity increased linearly with the increased supplementation, regardless of the source studied.
\end{abstract}

Key words: enzyme activity, glutathione peroxidase, hepatic selenium, plasmatic selenium.

Níveis dietéticos e fontes de selênio para leitões pós-desmame

RESUMO: Um experimento foi conduzido para estudar os efeitos de duas fontes e diferentes níveis de selênio (Se) sobre o desempenho, concentração de Se e atividade da glutationa peroxidase no plasma e fígado de leitões após o desmame. Um total de 126 leitões desmamados machos e fêmeas (Large White $\times$ Landrace), com peso corporal médio de 7,2 $\pm 0,67 \mathrm{~kg}$ foram distribuídos em sete tratamentos em delineamento em blocos casualizados, com duas fontes de Se (orgânico e inorgânico), com níveis de inclusão: dois níveis para a fonte inorgânica (0,30 e 0,60ppm), quatro para a fonte orgânica $(0,15,0,30,0,45$ e 0,60ppm) e uma dieta de controle sem suplemento de Se contendo 0,095ppm em seis repetições de três animais por baia. O periodo experimental foi de 35 dias após o desmame. A fonte orgânica continha 0,2067\% (Se-Levedura) e a inorgânica (Selenito de sódio) 45,86\% de Se analisado. Os leitões que receberam Se suplementar tiveram menor consumo de alimento em comparação com os que não foram suplementados. Além disso, a conversão alimentar foi melhor com a suplementação dietética de selênio e a fonte orgânica foi melhor do que a fonte inorgânica ao nível de 0,30ppm. A concentração plasmática de Se foi maior (35,53\%) nos animais que receberam suplementação dietética deste mineral, independentemente das fontes estudadas. Não houve efeito de fontes no Se plasmático e hepático, com os valores mais baixos observados para a não suplementação e Se orgânico no nível de dieta de 0,15ppm. Houve uma redução linear da atividade GSH-Px plasmática com níveis de suplementação aumentados de Se orgânico e a atividade hepática GSH-Px aumentou linearmente com o aumento da suplementação, independente da fonte estudada.

Palavras-chave: atividade enzimática, glutationa peroxidase, selênio hepático, selênio plasmático.

\section{INTRODUCTION}

The post weaning period is considered one of the most important phases in swine production, since piglets are exposed to stress factors that favor the development of pathogenic bacteria in the digestive tract, contributing to growth retardation and diarrhea during this period. In this regard, several measures can be taken to mitigate the adverse conditions of this phase, mainly in terms of well-being, thermal comfort, health and nutrition.

From a nutritional standpoint, adequate supplementation of organic selenium (Se), would be an alternative to minimize the problems during 
post weaning. Selenium has been show to have great importance for physiological functions and to improve performance (ZHAN et al., 2005) because it is indispensable in defending the body against free radicals causing oxidative damage of cell membranes (MAHAN et al., 1999; DOWNS et al., 2000; ZHAN et al., 2005). Stress by changing piglets diet and environment are important factors for the increase of free radicals. Moreover, the Se dietary sources studies, have shown that replacing inorganic by organic form, can increase both its absorption (MAHMOUD \& EDENS, 2003), and its biological activity (WANG \& XU, 2008; CAO et al., 2014).

The Se requirement for piglets has been established by NRC (2012) as $0.30 \mathrm{ppm}$ and ROSTAGNO et al. (2011) recommended $0.250 \mathrm{ppm}$ for all categories, from inorganic source only. However, ROSTAGNO et al. (2017) recommended for piglets post weaning $0.517 \mathrm{ppm}$ from inorganic source and $0.233 \mathrm{ppm}$ from organic sources.

The objective of this study was to evaluate the performance, plasma and hepatic Se concentrations, and activity of plasma and hepatic glutathione peroxidase (GSH-Px) of piglets in the post weaning phase with diets containing different dietary levels and sources of Se (organic and inorganic).

\section{MATERIALS AND METHODS}

One hundred and twenty six Large White $\mathrm{x}$ Landrace barrows and gilts weighing an average of $7.2 \pm 0.67 \mathrm{~kg}$ were assigned in a randomized block design, according to body weight, even dietary treatments, six replications, and housed three per pen $(2.0 \times 1.2 \mathrm{~m})$ with individual semi-automatic feeders and drinkers, in a completely-enclosed, slotted-floor, environmentally-controlled building, during the 35 days of the experimental period ( 28 to $63 \mathrm{~d}$ of age). Water and diet was provided ad libitum during the whole experiment. The averages temperature and relative humidity of the room during the experimental period was $27.5 \pm 3.1^{\circ} \mathrm{C}$ and $57.5 \%$, respectively. Sodium selenite ( $45.86 \%$ of Se analyzed) as inorganic and selenium yeast $(0.2067 \%$ of Se analyzed $)$ as organic sources were used, respectively (Table 1).

Ingredient and nutrient specifications of the diets in all diets were identical, and the rations only differed in Se levels (Table 2). Corn-soybean meal basal diet formulation and nutritional composition shown in table 2 and the dietary nutrient components were according ROSTAGNO et al. (2011). Content
Table 1 - Experimental diets and specifications.

\begin{tabular}{lc}
\hline Diets & Specifications \\
\hline 1 & Negative control without Se supplementation \\
2 & With $0.30 \mathrm{ppm}$ of sodium selenite $(45.86 \%)$ \\
3 & With $0.60 \mathrm{ppm}$ of sodium selenite $(45.86 \%)$ \\
4 & With $0.15 \mathrm{ppm}$ of selenium yeast $(0.2067 \%)$ \\
\hline 6 & With $0.30 \mathrm{ppm}$ of selenium yeast $(0.2067 \%)$ \\
\hline 7 & With $0.45 \mathrm{ppm}$ of selenium yeast $(0.2067 \%)$ \\
\hline
\end{tabular}

of Se analyzed in the basal diet was $0.095 \mathrm{ppm}$. Inorganic and organic Se sources was added using a premix with 1000ppm.

Every day the stalls were cleaned and animals fed with dry feed at $7 \mathrm{am}$ and $4 \mathrm{pm}$. At the end of the experiment an animal in each pen was slaughtered to collect blood and liver for the GSH-Px activity tests and selenium levels. The slaughters were according to Ministry of Agriculture Livestock and Food Supply (MAPA) standards. Blood collection proceeded after electric stunning of animals, during exsanguination. The blood collected in tubes containing anti-coagulant (sodium heparin) was centrifuged (Sigma 2-5) immediately at $3000 x$ for 10 minutes. After completion of the process, the plasma portion was pipetted, placed in a graduated Eppendorf microtube $(1.5 \mathrm{ml})$ and frozen at $-20^{\circ} \mathrm{C}$ for analysis of Se and the GSHPx activity. Selenium analyses were conducted by atomic absorption spectrometry in a Spectra 2000 apparatus (Varian, Australia), equipped with 77 VGA system for hydride generation and $10 \mathrm{~mA}$ cathode lamp (Varian, Melbourne, Australia). Digestion was carried out in a digester oven for simple digestion (Merck Darmstadt, Germany). The liver selenium content was performed on an L202 lyophilizer (Liobras), considering the initial weights and final samples. For the plasma samples preparation for reading the wet sample methodology was used. All quantitative analysis (digestion and reading) processes were performed by the same equipment mentioned above.

The readings of the GSH-Px were taken following the methodology described by LEVANDER et al. (1983) adapted by MOREIRA et al. (2001). Enzymatic activity readings were monitored by the change in spectrophotometer absorbance according to the oxidation of NADPH at $340 \mathrm{~nm}$, and the enzyme activity was expressed as mmol NADPH oxidized per minute. 
Table 2 - Experimental diet composition.

\begin{tabular}{|c|c|c|c|c|c|c|c|}
\hline \multirow{2}{*}{ Ingredient $(\%)$} & \multirow{2}{*}{$\begin{array}{c}\text { Control, ppm } \\
0.00\end{array}$} & \multicolumn{2}{|c|}{---Inorganic Se, ppm--- } & \multicolumn{4}{|c|}{-------------- Organic Se, ppm ---------------- } \\
\hline & & 0.30 & 0.60 & 0.15 & 0.30 & 0.45 & 0.60 \\
\hline Corn & 22.725 & 22.725 & 22.725 & 22.725 & 22.725 & 22.725 & 22.725 \\
\hline Soybean meal, $46 \%$ & 20.000 & 20.000 & 20.000 & 20.000 & 20.000 & 20.000 & 20.000 \\
\hline Micronized soybean & 15.000 & 15.000 & 15.000 & 15.000 & 15.000 & 15.000 & 15.000 \\
\hline Pre-gelatinized corn & 23.000 & 23.000 & 23.000 & 23.000 & 23.000 & 23.000 & 23.000 \\
\hline Soy oil & 1.000 & 1.000 & 1.000 & 1.000 & 1.000 & 1.000 & 1.000 \\
\hline Milk serum powder & 15.000 & 15.000 & 15.000 & 15.000 & 15.000 & 15.000 & 15.000 \\
\hline Dicalcium posphate & 1.380 & 1.380 & 1.380 & 1.380 & 1.380 & 1.380 & 1.380 \\
\hline Limestone & 0.750 & 0.750 & 0.750 & 0.750 & 0.750 & 0.750 & 0.750 \\
\hline Salt & 0.300 & 0.300 & 0.300 & 0.300 & 0.300 & 0.300 & 0.300 \\
\hline Vitamin premix $^{1}$ & 0.100 & 0.100 & 0.100 & 0.100 & 0.100 & 0.100 & 0.100 \\
\hline Mineral premix ${ }^{1}$ & 0.100 & 0.100 & 0.100 & 0.100 & 0.100 & 0.100 & 0.100 \\
\hline L-lysine-HCl,78\% & 0.370 & 0.370 & 0.370 & 0.370 & 0.370 & 0.370 & 0.370 \\
\hline DL-methionine, $9 \%$ & 0.080 & 0.080 & 0.080 & 0.080 & 0.080 & 0.080 & 0.080 \\
\hline L-threonine, $98,5 \%$ & 0.012 & 0.012 & 0.012 & 0.012 & 0.012 & 0.012 & 0.012 \\
\hline Zinc bacitracin, $15 \%$ & 0.050 & 0.050 & 0.050 & 0.050 & 0.050 & 0.050 & 0.050 \\
\hline Colistin sulfate, $8 \%$ & 0.025 & 0.025 & 0.025 & 0.025 & 0.025 & 0.025 & 0.025 \\
\hline Selenium yeast,2000ppm & 0.000 & 0.000 & 0.000 & 0.015 & 0.030 & 0.045 & 0.060 \\
\hline Sodium selenite, $45.6 \%$ & 0.000 & 0.030 & 0.060 & 0.000 & 0.000 & 0.000 & 0.000 \\
\hline Inert (kaolin) & 0.100 & 0.070 & 0.040 & 0.085 & 0.070 & 0.055 & 0.040 \\
\hline Total & 100.00 & 100.00 & 100.00 & 100.00 & 100.00 & 100.00 & 100.00 \\
\hline \multicolumn{8}{|c|}{ 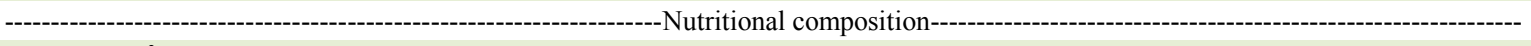 } \\
\hline ME, kcal kg ${ }^{-3}$ & 3421 & 3421 & 3421 & 3421 & 3421 & 3421 & 3421 \\
\hline $\mathrm{CP}, \%^{2}$ & 20.43 & 20.43 & 20.43 & 20.43 & 20.43 & 20.43 & 20.43 \\
\hline $\mathrm{Ca}, \%^{2}$ & 0.855 & 0.855 & 0.855 & 0.855 & 0.855 & 0.855 & 0.855 \\
\hline Total P, $\%^{2}$ & 0.629 & 0.629 & 0.629 & 0.629 & 0.629 & 0.629 & 0.629 \\
\hline Avail. $\mathrm{P}, \%^{3}$ & 0.444 & 0.444 & 0.444 & 0.444 & 0.444 & 0.444 & 0.444 \\
\hline $\mathrm{DM}, \%^{2}$ & 89.140 & 89.140 & 89.140 & 89.140 & 89.140 & 89.140 & 89.140 \\
\hline $\mathrm{CF}, \%^{2}$ & 2.460 & 2.460 & 2.460 & 2.460 & 2.460 & 2.460 & 2.460 \\
\hline Total Lysine, $\%^{3}$ & 1.550 & 1.550 & 1.550 & 1.550 & 1.550 & 1.550 & 1.550 \\
\hline Digest. Lysine, $\%^{3}$ & 1.333 & 1.333 & 1.333 & 1.333 & 1.333 & 1.333 & 1.333 \\
\hline Digest. Methionine, $\%^{3}$ & 0.377 & 0.377 & 0.377 & 0.377 & 0.377 & 0.377 & 0.377 \\
\hline Digest. Threonine, $\%^{3}$ & 0.837 & 0.837 & 0.837 & 0.837 & 0.837 & 0.837 & 0.837 \\
\hline Digest. Tryptophan, $\%^{3}$ & 0.221 & 0.221 & 0.221 & 0.221 & 0.221 & 0.221 & 0.221 \\
\hline $\mathrm{Se}, \%^{4}$ & 0.095 & 0.290 & 0.650 & 0.180 & 0.300 & 0.490 & 0.680 \\
\hline
\end{tabular}

${ }^{1}$ Provided the following per kilogram of diet: Vit. A, 15.000IU; Vit. $\mathrm{D}_{3}, 2.000 \mathrm{IU}$; Vit. E, 100IU; Vit. $\mathrm{K}_{3}, 3.3 \mathrm{mg}$; Vit. B 12 , 12.5 $\mu$ g; folacin, $2.5 \mathrm{mg}$; phantotenic acid, $15.0 \mathrm{mg}$; biotin, $0.2 \mathrm{mg}$; niacin, $30.0 \mathrm{mg}$; pyridoxine, $5.0 \mathrm{mg}$; riboflavin, $6.5 \mathrm{mg}$; thiamine, $3.0 \mathrm{mg}$; antioxidant: $1.5 \mathrm{mg}$; copper, $6 \mathrm{mg}$; iron, $100 \mathrm{mg}$; iodine, $0,14 \mathrm{mg}$; manganese, $4 \mathrm{mg}$; zinc, $100 \mathrm{mg}$.

${ }^{2}$ AOAC Analysis of the Association of Official Analytical Chemists (2000).

${ }^{3}$ According to ROSTAGNO et al. (2011).

${ }^{4}$ Analyzed by atomic absorption spectrometry equipped with 77 VGA System for Generator Hydrides

Controls tubes were without substrate (blank enzyme) as comparison. The analyzed variables were weight gain (WG), feed intake (FI), feed conversion (FC), and plasma and liver contents and glutathione peroxidase activity according dietary levels and sources of selenium.
Data were submitted to analysis of variance using proc GLM of SAS - Statistical Software (2000). Orthogonal contrasts $(P<0.05)$ were performed to compare the control average with the average of the other treatments supplemented with selenium, to compare mean levels of each 
source and to compare the means among sources. Regression analysis was applied for dietary Se levels within each source.

\section{RESULTS AND DISCUSSION}

Dietary Se levels and sources had no effect on WG $(P>0.05)$, on the other hand, the FI and FC were influenced $(P<0.05)$ (Table 3$)$. The piglets that received supplemental Se showed lower feed intake (FI) and better feed conversion $(P<0.05)$, compared to those without supplementation. Comparing the NRC (2012) recommendation of supplementation there are no differences $(P>0.05)$ in feed intake between the inorganic and organic forms of the mineral. Reduction in the FI of growing-finishing pigs was observed by KIM \& MAHAN (2001); however, with higher dietary Se levels $(>5 \mathrm{ppm})$. These results cannot be physiologically explained.

It was observed that regardless of the Se level and source, the supplementation improved
FC $(P<0.05)$. Increase of Se supplementation in the organic source improved (linear effect) in the FC of the pigs $(P<0.05)$. According to NRC (2012) recommendation, the organic source was better than inorganic to $\mathrm{FC}(P<0.05)$. On the other hand, no differences $(P>0.05)$ were observed to $\mathrm{FC}$ between the supplementation of 0.15 and $0.30 \mathrm{ppm}$ of $\mathrm{Se}$ in the organic form. CAO et al. (2014) observed that Se supplementation improved the FC on the piglets regardless of source and the organic Se was not showed difference between levels ( 0.10 to $0.70 \mathrm{ppm})$. According to MOREIRA et al. (2001), the organic Se provides greater availability of biologically active $\mathrm{Se}$ in the blood and greater deposition of Se in the tissues. In fact, ZHAN et al. (2005) observed that the addition of organic Se to growing and finishing pigs increased the deposition of Se in the tissues, improved the antioxidant ability to protect the myoglobin and to preserve the integrity of the cell membrane. Thus, a possible explanation for the improved FC of piglets supplemented with the

Table 3 - Initial and final weight, daily feed intake, daily weight gain, and feed conversion of piglets according to sources and Se levels during 35 experimental days*.

\begin{tabular}{|c|c|c|c|c|c|c|c|}
\hline \multirow{2}{*}{$\begin{array}{l}\text { Se suppl. Levels } \\
(\mathrm{ppm})\end{array}$} & \multirow{2}{*}{ 0.000} & \multicolumn{2}{|c|}{----------Inorganic---------- } & \multicolumn{4}{|c|}{ 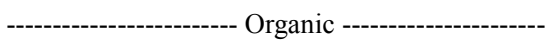 } \\
\hline & & 0.300 & 0.600 & 0.150 & 0.300 & 0.450 & 0.600 \\
\hline Initial weight, kg & 7.213 & 7.201 & 7.183 & 7.155 & 7.172 & 7.226 & 7.168 \\
\hline Final weight, kg & 23.971 & 22.582 & 22.614 & 23.435 & 23.225 & 23.367 & 22.766 \\
\hline Weight Gain, kg & 0.479 & 0.440 & 0.441 & 0.465 & 0.459 & 0.461 & 0.446 \\
\hline \multicolumn{8}{|c|}{ } \\
\hline Feed Intake ${ }^{1}, \mathrm{~kg}$ & 0.770 & 0.690 & 0.670 & 0.710 & 0.690 & 0.680 & 0.650 \\
\hline Feed Intake, ${ }^{2}, \mathrm{~kg}$ & $0.770 \mathrm{a}$ & & & \multicolumn{4}{|c|}{$0.682 b$} \\
\hline Feed Intake, ${ }^{3}$ & & \multicolumn{2}{|c|}{$0.690 \mathrm{a}$} & \multicolumn{4}{|c|}{$0.690 \mathrm{a}$} \\
\hline Feed Intake, & & \multicolumn{2}{|c|}{$0.710 \mathrm{a}$} & \multicolumn{4}{|c|}{$0.690 \mathrm{a}$} \\
\hline \multicolumn{8}{|c|}{ - CV $(\%)=7.21-1$} \\
\hline Feed Conversion ${ }^{5}$ & 1.608 & 1.568 & 1.519 & 1.527 & 1.503 & 1.475 & 1.457 \\
\hline Feed Conversion $^{2}$ & $1.608 \mathrm{~b}$ & & & \multicolumn{4}{|c|}{$1.508 \mathrm{a}$} \\
\hline Feed Conversion ${ }^{3}$ & & \multicolumn{2}{|c|}{$1.568 \mathrm{~b}$} & \multicolumn{4}{|c|}{$1.503 \mathrm{a}$} \\
\hline Feed Conversion ${ }^{4}$ & & \multicolumn{2}{|c|}{$1.527 \mathrm{a}$} & \multicolumn{4}{|c|}{$1.503 \mathrm{a}$} \\
\hline
\end{tabular}

*Means followed by the same letter in the row do not differ from each other according to orthogonal contrasts.

${ }^{1}$ Linear effect $(P<0.05)$ in the organic Se levels $\left(Y=0.730-0.1267 \mathrm{X}, \mathrm{r}^{2}=0.96\right)$.

${ }^{2}$ Average of the control treatment compared to other treatments supplemented with Se $(P<0.05)^{3}$ Average organic source compared with inorganic Se source at the $0.30 \mathrm{ppm}$ level $(P<0.05)$.

${ }^{4}$ Average of the $0.15 \mathrm{ppm}$ with $0.30 \mathrm{ppm}$ organic source $(P>0.05)$.

${ }^{5}$ Linear effect $(P<0.05)$ in the organic Se levels $\left(\mathrm{Y}=1.550-0.1587 \mathrm{X}, \mathrm{r}^{2}=0.99\right)$. 
organic source is that it can result in a more effective cellular response by providing a steady state delivery of Se response to a deficiency of Se in conditions where the body of the pig is challenged. Plasma and liver Se concentrations increased linearly $(\mathrm{P}<0.05)$ with supplementation increase (organic source), and higher $(P<0.05)$ for animals receiving dietary supplementation of this mineral (Table 4), regardless of the sources studied. There was no effect $(P>0.05)$ of the sources on the plasma and liver concentration of Se for the supplements of $0.30 \mathrm{ppm}$; however, lower level to $0.15 \mathrm{ppm}$ compared with $0.30 \mathrm{ppm}$ to organic form $(P<0.05)$ was observed.

According to HERDT et al. (2000), the blood Se concentration is an important indicator of recent intake of Se by an animal. Likewise, according to VALK \& HORSTRA (2000), the concentration of Se in the liver provides an accurate indication of intake of Se. YOON \& McMILLAN (2006) and MAHAN et al. (2000), reported that the use of organic Se in the diets of mothers increased the concentration of $\mathrm{Se}$ in blood of piglets at birth. Results of our research, showed that supplementary Se over 0.300ppm do not alter their concentration in plasma, but the liver Se contents markedly increased as the dietary Se level increased, regardless of source.
As for the activity of plasma GSHPx in (Table 5), it appears that piglets without supplementation of Se in their diet had higher activity of this enzyme in relation to those receiving inorganic or organic Se in the diet $(\mathrm{P}<0.05)$. This observation is contradictory for many authors and suggested that the content of selenium in the basal diet was sufficient to maintain the enzyme activity. CAO et al. (2014) observed that the highest serum and muscle GSH-Px activity was reported in treatment fed with $0.30 \mathrm{ppm}$ of organic Se compared to control treatment (low-Se) and the $0.30 \mathrm{ppm}$ sodium selenite groups. SUNDE (2001) noted that the enzyme activity was stabilized after $0.1 \mathrm{ppm}$. The basal diet contained $0.092 \mathrm{ppm}$ in this research.

In addition, there was effect of Se sources on the activity of GSH-Px in plasma $(P<0.05)$, when compared with the same dietary levels $(0.300 \mathrm{ppm})$. Animals supplemented with organic Se had, compared to those receiving the inorganic source, the lower GSH-Px plasma activity. When the activity of GSHPx was compared within each source, we observed that as the level of supplementation increased, the GSH-Px plasma activity decreased $(P<0.05)$ for inorganic (0.300 to $0.600 \mathrm{ppm})$ and organic sources (0.15 to $0.45 \mathrm{ppm})$.

Table 4 - Plasma and liver Se contents (ppm) of piglets according sources and Se levels during 35 experimental days.

\begin{tabular}{|c|c|c|c|c|c|c|c|}
\hline \multirow{2}{*}{$\begin{array}{l}\text { Analysis } \\
\text { Se suppl. levels (ppm) }\end{array}$} & \multirow{2}{*}{$\begin{array}{c}\text { Control } \\
0.000\end{array}$} & \multicolumn{2}{|c|}{-----------Inorganic----------- } & \multicolumn{4}{|c|}{--------------------Organic----------------- } \\
\hline & & 0.300 & 0.600 & 0.150 & 0.300 & 0.450 & 0.600 \\
\hline Plasma Se $^{1}$ & 0.043 & 0.132 & 0.135 & 0.063 & 0.121 & 0.124 & 0.153 \\
\hline Plasma Se ${ }^{2}$ & $0.043 b$ & & & \multicolumn{4}{|c|}{$0.121 \mathrm{a}$} \\
\hline Plasma $\mathrm{Se}^{3}$ & & \multicolumn{2}{|c|}{$0.132 a$} & \multicolumn{4}{|c|}{$0.121 \mathrm{a}$} \\
\hline Plasma Se ${ }^{4}$ & & & & \multicolumn{2}{|c|}{$0.063 \mathrm{~b}$} & \multicolumn{2}{|c|}{$0.121 \mathrm{a}$} \\
\hline \multicolumn{8}{|c|}{ 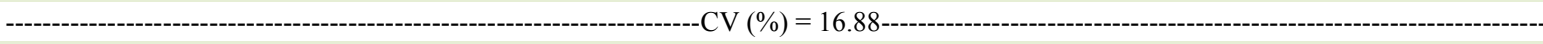 } \\
\hline Liver $\mathrm{Se}^{5}$ & 0.030 & 0.810 & 1.192 & 0.423 & 0.885 & 1.061 & 1.251 \\
\hline Liver $\mathrm{Se}^{2}$ & $0.030 \mathrm{~b}$ & & & \multicolumn{4}{|c|}{$0.937 \mathrm{a}$} \\
\hline Liver $\mathrm{Se}^{3}$ & & \multicolumn{2}{|c|}{$0.810 \mathrm{a}$} & \multicolumn{4}{|c|}{$0.885 \mathrm{a}$} \\
\hline Liver $\mathrm{Se}^{4}$ & & & & \multicolumn{2}{|c|}{$0.423 b$} & \multicolumn{2}{|c|}{$0.885 \mathrm{a}$} \\
\hline
\end{tabular}

*Means followed by the same letter in the row do not differ from each other according to orthogonal contrasts.

${ }^{1}$ Linear effect $(P<0.05)$ in the organic Se levels $\left(Y=0.047+0.182 \mathrm{X}, \mathrm{r}^{2}=0.87\right)$.

${ }^{2}$ Average of the control treatment compared to other treatments supplemented with $\mathrm{Se}(P<0.05)$.

${ }^{3}$ Average organic source compared with inorganic Se source at the $0.30 \mathrm{ppm}$ level $(P<0.05)$.

${ }^{4}$ Average of the $0.15 \mathrm{ppm}$ with $0.30 \mathrm{ppm}$ organic source $(P>0.05)$.

${ }^{5}$ Linear effect $(P<0.05)$ in the organic Se levels $\left(\mathrm{Y}=0.24+1.773 \mathrm{X}, \mathrm{r}^{2}=0.94\right)$ 
Table 5 - Plasma and hepatic activities of GSH-Px ( $\mu \mathrm{mol}$ of NADPH/min) of piglets, according sources and Se levels during 35 experimental days.

\begin{tabular}{|c|c|c|c|c|c|c|c|}
\hline \multirow{2}{*}{$\begin{array}{l}\text { Analysis } \\
\text { Se suppl. levels (ppm) }\end{array}$} & \multirow{2}{*}{$\begin{array}{c}\text { Control } \\
0.000\end{array}$} & \multicolumn{2}{|c|}{----------Inorganic---------- } & \multicolumn{4}{|c|}{ 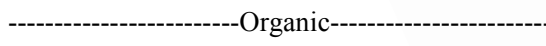 } \\
\hline & & 0.300 & 0.600 & 0.150 & 0.300 & 0.450 & 0.600 \\
\hline Plasma activities of GSH-Px & 7.491 & 7.542 & 7.351 & 6.794 & 6.695 & 6.513 & 6.612 \\
\hline Plasma activities of GSH-Px ${ }^{2}$ & $7.491 \mathrm{a}$ & & & \multicolumn{4}{|c|}{$6.918 b$} \\
\hline Plasma activities of GSH-Px ${ }^{3}$ & & \multicolumn{2}{|c|}{$7.542 \mathrm{a}$} & \multicolumn{4}{|c|}{$6.695 b$} \\
\hline Plasma activities of GSH-Px ${ }^{4}$ & & & & \multicolumn{2}{|c|}{$6.794 \mathrm{a}$} & \multicolumn{2}{|c|}{$6.695 \mathrm{~b}$} \\
\hline \multicolumn{8}{|c|}{ - } \\
\hline Hepatic activities of GSH-Px ${ }^{1}$ & 13.641 & 15.831 & 18.574 & 13.693 & 14.092 & 14.385 & 16.052 \\
\hline Hepatic activities of GSH-Px² & $13.641 \mathrm{~b}$ & & & \multicolumn{4}{|c|}{$15.438 \mathrm{a}$} \\
\hline Hepatic activities of GSH-Px ${ }^{3}$ & & \multicolumn{2}{|c|}{$15.831 \mathrm{a}$} & \multicolumn{4}{|c|}{$14.092 b$} \\
\hline Hepatic activities of GSH-Px ${ }^{4}$ & & & & \multicolumn{2}{|c|}{$13.693 b$} & \multicolumn{2}{|c|}{$14.092 \mathrm{a}$} \\
\hline
\end{tabular}

*Means followed by the same letter in the row do not differ from each other according to orthogonal contrasts.

${ }^{1}$ Linear effect $(P<0.05)$ in the organic Se levels $\left(\mathrm{Y}=12.713+4.9133 \mathrm{X}, \mathrm{r}^{2}=0.84\right)$.

${ }^{2}$ Average of the control treatment compared to other treatments supplemented with $\mathrm{Se}(P<0.05)$.

${ }^{3}$ Average organic source compared with inorganic Se source at the $0.30 \mathrm{ppm}$ level $(P<0.05)$.

${ }^{4}$ Average of the 0.15 ppm with $0.30 \mathrm{ppm}$ organic source $(P<0.05)$.

There was a linear increase $(\mathrm{P}<0.05)$ in the hepatic GSH-Px activity as the dietary levels increased (Figure 1), independently of source. According to ACDA \& CHAE (2002) there is a greater deposition of Se in tissues, when the organic source is used; however, the inorganic source increases the hepatic activity of GSH-Px. In fact, there was increased hepatic glutathione activity with increasing supplementation with inorganic selenium. Conversel, the increase of the organic source also resulted in increased activity of the enzyme in the liver of piglets.

Results of the present study showed that the recommendations of Se for piglets of $0.300 \mathrm{ppm}$ recommended by the NRC (2012) are suitable for both organic and inorganic sources; however, recent recommendations suggested a lower inclusion of organic Se for piglets in post-weaning $0.233 \mathrm{ppm}$ (ROSTAGNO et al., 2017).

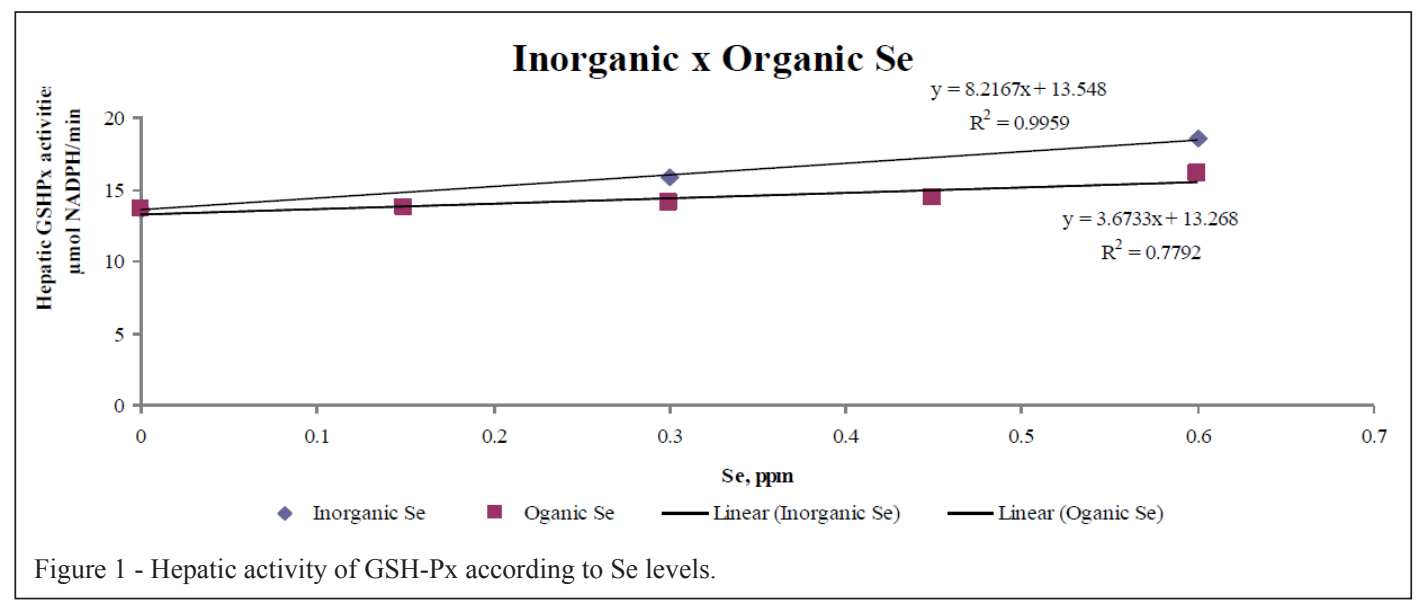

Ciência Rural, v.47, n.12, 2017. 


\section{CONCLUSION}

The dietary supplementation of selenium improved the feed conversion without influence on the weight gain of piglets.

The feed conversion was better for the organic selenium source.

The liver and plasma selenium concentration increase with the selenium supplementation, regardless the source (organic or inorganic).

The plasma activity of GSH-Px decreased with the increase of the supplementation, regardless of selenium source.

The hepatic activity of GSH-Px is increased with increasing selenium supplementation, regardless of the source studied.

This study confirmed the recommendation of $0.300 \mathrm{ppm}$ of $\mathrm{Se}$ as suitable for piglet diets regardless of source.

\section{ACKNOWLEDGEMENTS}

Fundação de Amparo a Pesquisa de Minas Gerais (FAPEMIG) for financial support for this publication.

\section{BIOETHICS AND BIOSSECURITY COMMITTEE APPROVAL}

This research was approved by the Bioethics Committee of Universidade Federal de Lavras (UFLA), Minas Gerais, Brazil, protocol number 006/2016.

\section{REFERENCES}

ACDA, S.P.; CHE, B.J. A review on the applications of organic trace minerals in pig nutrition. Pakistan Journal of Nutrition, v.1, p.25-30, 2002. Available from: <http://citeseerx.ist.psu.edu/viewdoc/download? doi=10.1.1.598.1460\&rep=rep1\&type=pdf $>$. Accessed: Apr. 20, 2017.

$\mathrm{CAO}$, J. et al. Effects of dietary Selenomethionine supplementation on growth performance, antioxidant status, plasma selenium concentration, and immune function in weaning pigs. Journal of Animal Science and Biotechnology, v.46, n.5, p.1-7, 2014. Available from: <https://www. ncbi.nlm.nih.gov/pmc/articles/PMC4198736/>. Accessed: Mar, 10, 2017. doi: 10.1186/2049-1891-5-46.

DOWNS, K.M. et al. Selenium source effect on broiler carcas characteristics, meat quality and drip loss. Journal Applied Animal Research, v.18, p.61-72, 2000. Available from: $<\mathrm{http} / /$ www.tandfonline.com/doi/pdf/10.1080/09712119.2000.9706324>. Accessed: Mar, 10, 2017. doi: 10.1080/09712119.2000.9706324.

HERDT, T.H. et al. The use of blood analyses to evaluate mineral status in livestock. Veterinary Clinics of North America: Food Animal Practice, v.16, p.423-444, 2000. Available from: <http://www.vetfood.theclinics. com/article/S0749-0720(11)00006-5/pdf $>$. Accessed: Feb, 25, 2017.

KIM, Y.Y.; MAHAN, D.C. Comparative effects of high dietary levels of organic and inorganic selenium on selenium toxicity of growing-finishing pigs. Journal of Animal Science, v.79, n.7, p.942-948, 2001. Available from: <https://www.researchgate.net/ publication/12011441_Comparative_effects_of_high_dietary_leleve of_organic_and_inorganic_selenium_on_selenium_toxicity_of growing-finishing_pigs $>$. Accessed: Feb, 23, 2017.

MAHAN, D.C. et al. Effects of dietary levels os Se-enriched yeast and sodium selenite as Se source fed to growing-finishing pigs on performance, tissue glutathione peroxidase activity, carcass characteristics and loin quality. Journal of Animal Science, v.77, n.12, p.2172-2179, 1999.

MAHAN, D.C. Effect of organic and inorganic selenium sources and levels on sow colostrum and milk selenium content. Journal of Animal Science, v.78, n.1, p.100-105, 2000.

MAHMOUD, K.Z.; EDENS, F.W. Influence of selenium sources on age related and mild heat stress-related changes of blood and liver glutathione redox cycle in broiler chickens. Compendium Biochemistry Physiology, v.136, p.921-934, 2003. Available from: <https://www.ncbi. nlm.nih.gov/pubmed/14662314>. Accessed: Mar, 20, 2017.

MOREIRA, J. et al. Efeitos de fonte e níveis de selênio na atividade enzimática da glutationa peroxidase e no desenvolvimento do frango de corte. Ciênc. agrotec.,Lavras, v.25,n.3,p.645-649, 2001.Available from: $<$ http:/www.editora.ufla.br/index.php/component/phocadownload/ category/41-volume-25-numero-3?download=699:vol25numero3 $>$. Accessed: Apr, 01, 2017

ROSTAGNO, H.S. et al. Tabelas brasileiras para aves e suínos: composição de alimentos e exigências nutricionais. $3^{\text {rd }}$ ed. Viçosa, MG: UFV, 2011. 186p.

ROSTAGNO, H.S. et al. Tabelas brasileiras para aves e suínos: composição de alimentos e exigências nutricionais. $4^{\text {th }} \mathrm{ed}$. Viçosa, MG: UFV, 2017. 488p.

SAS Institute Inc. SAS System for Microsoft Windows. Cary NC 2000. Release 6.12

SUNDE, R.A. Regulation of selenoprotein expression. In: HATFIELD, D.L. (Ed.). Se: its molecular biology and role in human health. Dordrecht, Netherlands: Kluwer Academic Publishers, 2001. p.81-96.

VALK, E.E.; HORNSTRA, G. Relationship between vitamin E requirement and polyunsatured fatty acid intake in man: a review. International Journal Vitamin Nutrition Research, v.70, p.30-41,2000. Available from: <https://www.ncbi.nlm.nih.gov/pubmed/10804454>. Accessed: Mar, 15, 2017. doi: 10.1024/0300-9831.70.2.31.

YOON, I.; MCMILLAN, E. Comparative effects of organic and inorganic selenium on selenium transfer from sows to nursing pigs. Journal of Animal Science, v.84, n.8, p.1729-1733, 2006. Available from: $<\mathrm{https}: / /$ pdfs.semanticscholar.org/e44d/16fb77fa13453fc0e7a132be4e32f7a718 db.pdf>. Accessed: Mar, 20, 2017. doi: 10.2527/jas.2005-311.

ZHAN, X.A. et al. Effects of different selenium source on selenium distribution, loin quality and antioxidant status in finishing pigs. Animal Feed Science and Technology, v.132, p.202-211, 2005. Available from: <http://www.journals.elsevierhealth.com/article/ S0377-8401(06)00154-4/pdf>. Accessed: Feb, 20, 2017.

WANG, Y.B.; XU, B.H. Effect of different selenium source (sodium selenite and selenium yeast) on broiler chickens. Animal Feed Science and Technology, v.144, p.306-314, 2008. Available from: <http:// www.journals.elsevierhealth.com/article/S0377-8401(07)00423-3/ pdf>. Accessed: Mar, 20, 2017. 